\title{
MECHANICAL BEHAVIOR AND MICROSTRUCTURE EVOLUTION OF Ti-6Al-4V WIRE ROD FOR PRODUCING AEROSPACE FASTENERS
}

\author{
MEHANSKE LASTNOSTI IN RAZVOJ MIKROSTRUKTURE ŽICE \\ IZ Ti-6Al-4V ZLITINE ZA IZDELAVO LETALSKIH SPONK
}

\author{
Yujia $\mathrm{Hu}^{1}$, Yuanming Huo ${ }^{\text {* }}$, Tao $\mathrm{He}^{1}$, Yong $\mathrm{Xue}^{2}$, Wanbo Yang ${ }^{1}$, Menglan Shen ${ }^{1}$ \\ ${ }^{1}$ School of Mechanical and Automotive Engineering, Shanghai University of Engineering Science, Shanghai 201620, China \\ ${ }^{2}$ School of Material Science and Engineering, North University of China, Taiyuan,030051, China \\ Prejem rokopisa - received: 2020-01-04; sprejem za objavo - accepted for publication: 2020-03-29
}

doi: $10.17222 / \mathrm{mit} .2020 .005$

\begin{abstract}
The basic deformation parameters had a significant influence on the mechanical behaviour and microstructure evolution of a Ti-6Al-4V wire rod. Compression experiments were conducted to study the effect of the deformation temperatures $\left(25-900{ }^{\circ} \mathrm{C}\right)$ and strain rates $(0.1 / \mathrm{s}, 1 / \mathrm{s}$ and $10 / \mathrm{s})$ on the mechanical behaviour and microstructure evolution. The microstructure observation and the quantitative metallographic of Ti-6Al-4V wire rod were investigated after the compression experiments. The results showed that the Ti-6Al-4V compressed samples tend to be cracked along a $45^{\circ}$ angle below $300{ }^{\circ} \mathrm{C}$, which was regarded as the critical deformation temperature. Deformation temperatures from $400{ }^{\circ} \mathrm{C}$ to $600{ }^{\circ} \mathrm{C}$ can be regarded as the warm deformation region. Deformation temperatures from $700{ }^{\circ} \mathrm{C}$ to $900{ }^{\circ} \mathrm{C}$ can be regarded as the hot deformation region. And the softening mechanism was predominated by a temperature rise and dynamic recrystallization, respectively, for the warm deformation region and the hot deformation region of the Ti-6Al-4V alloy.

Keywords: Ti-6Al-4V wire rod, mechanical behavior, microstructure evolution, deformation temperatures, deformation rates

Osnovni parametri deformacije imajo pomemben vpliv na mehansko obnašanje in razvoj mikrostrukture žice iz Ti-6Al-4V zlitine. Avtorji članka so izvedli tlačne preizkuse na vzorcih žice premera $10 \mathrm{~mm}$, da bi ugotovili vpliv deformacije na mehanske lastnosti in razvoj mikrostrukture pri hitrostih deformacij $0,1 \mathrm{~s}^{-1}, 1 \mathrm{~s}^{-1}$ in $10 \mathrm{~s}^{-1}$ in v področju temperatur med $25^{\circ} \mathrm{C}$ in $900{ }^{\circ} \mathrm{C}$. Po tlačnih preizkusih so izvedli mikrostrukturne preiskave pri različnih pogojih deformirane Ti-6Al-4V žice in izvedli kvantitativne metalografske analize nastalih mikrostruktur. Rezultati analiz so pokazali, da imajo tlačno deformirani vzorci iz Ti-6Al-4V zlitine tendenco pokanja vzdolž kota $45^{\circ}$ pri temperaturah pod $300{ }^{\circ} \mathrm{C}$, ki so jo zato ocenili kot kritično temperaturo deformacije. Deformacije pri temperaturah med $400{ }^{\circ} \mathrm{C}$ in $600{ }^{\circ} \mathrm{C}$, so avtorji ocenili kot področje tople deformacije medtem, ko lahko deformacije pri temperaturah med $700{ }^{\circ} \mathrm{C}$ in $900{ }^{\circ} \mathrm{C}$ smatramo kot področje v katerem poteka vroča deformacija. Mehanizem mehčanja materiala je bil prednostno odvisen od naraščanja temperature in dinamične rekristalizacije $\mathrm{v}$ področjih tople in vroče deformacije Ti-6Al-4V zlitine.

Ključne besede: žica iz Ti-6Al-4V zlitine, mehanske lastnosti, razvoj mikrostrukture, temperatura in hitrost deformacije
\end{abstract}

\section{INTRODUCTION}

As a kind of medium strength $\alpha+\beta$ type two-phase titanium alloy, ${ }^{1,2}$ the weight of Ti-6Al-4V alloy is $30 \%$ lighter than that of steel, ${ }^{3}$ but its strength is three times higher than steel. ${ }^{4}$ In addition, the Ti-6Al-4V alloy has properties against corrosion, which make it an idea material to produce aerospace fasteners. ${ }^{5,6}$ The detailed manufacturing process parameters have great effects on the microstructure distribution of aerospace fasteners. ${ }^{7}$ It is necessary to investigate the effects of deformation temperatures and deformation rates on the mechanical behaviour and microstructure evolution of a Ti-6Al-4V wire rod.

Currently, the mechanical behaviour and microstructure evolution of the Ti-6Al-4V alloy have been widely reported. H. J. Mao et al. ${ }^{8}$ studied the microstructure and properties of Ti-6Al-4V in the range $700-900{ }^{\circ} \mathrm{C}$. Z. Q.

*Corresponding author's e-mail:

yuanming.huo@sues.edu.cn (Yuanming Huo)
Wu et al. ${ }^{9}$ investigated the effect of the solution temperature and wire size on the microstructure, mechanical properties and phase structure of a Ti-6Al-4V wire rod. H. J. Mao et al. ${ }^{10}$ investigated the deformation behavior of the Ti-6Al-4V alloy under different temperatures and strain rates. B. L. Luo et al. ${ }^{11}$ analyzed the uniformity of the microstructure of TC4 titanium alloy bars under different heating temperatures. However, the investigation on the effect of the detailed manufacturing process parameters on the mechanical behavior and microstructure evolution of Ti-6Al-4V wire rod are rarely found.

In the present work, the effects of processing parameters, including deformation temperatures and deformation rates, on the formability, mechanical behavior and microstructure evolution were investigated based on quantitative metallography of a compressed Ti-6Al-4V wire rod. Meanwhile, the flow softening mechanism of the Ti-6Al-4V wire rod during warm compression was also analysed. 


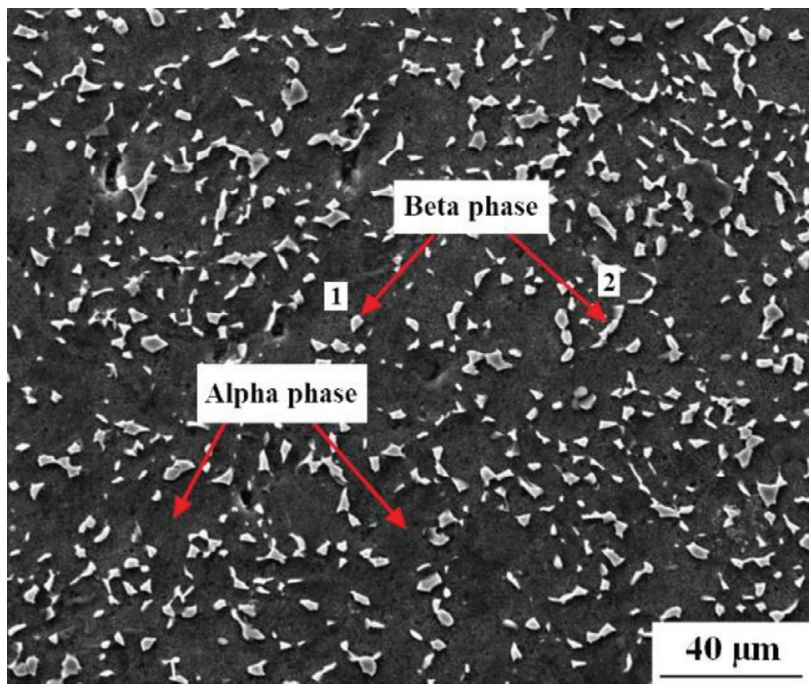

Figure 1: SEM microstructure of Ti-6Al-4V alloy wire rod in annealed state (1- granular beta phase, 2- long-strip beta phase)

\section{EXPERIMENTAL PART}

The as-supplied state of the Ti-6Al-4V alloy wire rod is an annealing treatment after drawing. The main chemical composition $(w / \%)$ of the Ti-6Al-4V wire rod includes: $6.20 \% \mathrm{Al}, 4.15 \% \mathrm{~V}, 0.15 \% \mathrm{O}, 0.05 \% \mathrm{Fe}$, $0.01 \% \mathrm{C}, 0.015 \% \mathrm{~N}, 0.0016 \% \mathrm{H}$ and the bal. Ti. The cylindrical compression specimens were prepared with $10.0 \mathrm{~mm}$ diameter and $12.0 \mathrm{~mm}$ height. Figure 1 shows
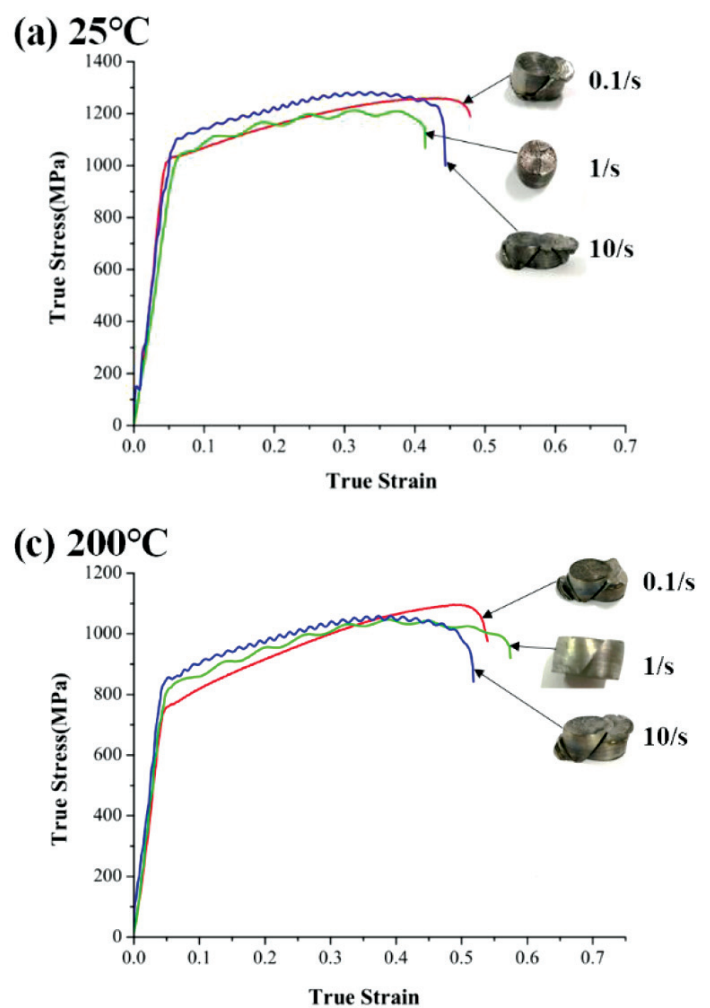

a micrograph of Ti-6Al-4V alloy wire rod in the annealed state. It can be seen from Figure 1 that the microstructure at room temperature is composed of granular beta phase, long-strip beta phase and alpha phase as the matrix.

Compression experiments were conducted on an American DSI Gleeble-3800 Thermal Simulation Tester. $^{12}$ A layer of $\Phi 12 \mathrm{~mm} \times 0.25 \mathrm{~mm}$ graphite sheet was clamped between the indenter and the ends of the sample for lubrication. The test pieces were heated to a deformation temperature $\left(25-900{ }^{\circ} \mathrm{C}\right)$ at a heating rate of $5{ }^{\circ} \mathrm{C} / \mathrm{s}$, and then compressed and deformed at a strain rate of $0.1 / \mathrm{s}, 1 / \mathrm{s}$ and $10 / \mathrm{s}$. Water quenching was performed immediately to retain the microstructure after compression deformation.

The specimens were taken from the compressed test pieces by using a wire-cutting machine, and the specimens were embedded in cold mounting resin. The surface of the specimens was grinded first with coarse 400 -grit abrasive paper to remove scratch marks caused by wire cutting, followed by finer 600-, 800-, 1000-, 1200- and 1500-grit abrasive paper. ${ }^{13}$ And the surfaces of the specimens were finally polished to a mirror surface using a polishing machine. After the polishing was completed, the specimens were cleaned twice. The specimen surface was wiped with a cotton ball and alcohol to remove the residual polish paste. And then the sample was put in acetone solution and shaken it to clean the impurities inside the specimens.
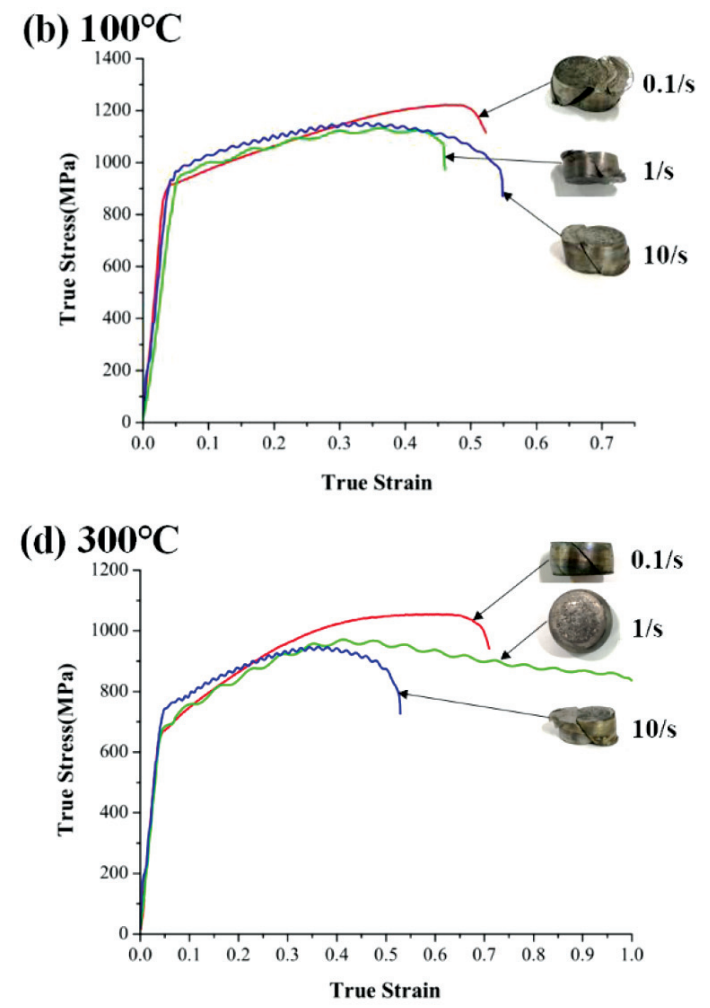

Figure 2: Compressed samples and the stress-strain relationships of Ti-6Al-4V at the deformation temperature of: a) $25{ }^{\circ} \mathrm{C}$, b) $100{ }^{\circ} \mathrm{C}$, c) $200{ }^{\circ} \mathrm{C}$ and d) $300{ }^{\circ} \mathrm{C}$ 
After the washes were completed two times, the specimens could be etched. The etching solution consists of $2.5 \mathrm{~mL} \mathrm{HF}, 3 \mathrm{~mL} \mathrm{HNO}_{3}, 5 \mathrm{~mL} \mathrm{HCl}$ and $91 \mathrm{~mL} \mathrm{H}_{2} \mathrm{O}^{14}$. The corrosion time of medium and low temperature compression specimens was 3-5 s, and the corrosion time of the high-temperature compression specimens was $8-10 \mathrm{~s}$. After the corrosion, the specimen surface was rinsed with purified water, dried with a blower, and the microstructure of the Ti-6Al-4V alloy wire rod was observed with a JSM-6460 Scanning Electron Microscope (SEM).

\section{EXPERIMENTAL RESULTS AND DISCUSSION}

\subsection{Effect of deformation temperatures on the forma- bility}

Figure 2 shows the compressed test pieces and its stress-strain relationships of Ti-6Al-4V at the deformation temperatures of $25^{\circ} \mathrm{C}, 100{ }^{\circ} \mathrm{C}, 200{ }^{\circ} \mathrm{C}$ and $300{ }^{\circ} \mathrm{C}$. As is seen from Figure 2, when the deformation temperature is below $300{ }^{\circ} \mathrm{C}$, the test pieces were fractured in a direction of $45^{\circ}$ with respect to the direction of compression. This is because the shear stress in the direction of $45^{\circ}$ is the largest during compression. At low temperatures, the plasticity of the Ti-6Al-4V wire rod is worse and adverse to metal flow. It can be concluded that $300{ }^{\circ} \mathrm{C}$ is the critical deformation temperature of the Ti-6V-4V alloy. The Ti-6Al-4V wire rod has poor formability when the deformation temperature is below $300{ }^{\circ} \mathrm{C}$, which should be avoided in the actual production process. ${ }^{15}$

\subsection{Effect of deformation temperatures on the mecha- nical behavior and microstructure evolution}

Figure 3 shows the stress-strain relationships of the Ti-6Al-4V wire rod at deformation temperatures of $400{ }^{\circ} \mathrm{C}, 500{ }^{\circ} \mathrm{C}, 600{ }^{\circ} \mathrm{C}, 700{ }^{\circ} \mathrm{C}, 800{ }^{\circ} \mathrm{C}, 900{ }^{\circ} \mathrm{C}$ with strain rates of $0.1 / \mathrm{s}, 1 / \mathrm{s}$ and $10 / \mathrm{s}$. It can be seen from Figure 3 that during the deformation process, the flow stress rapidly rises to the peak value and then exhibits a dynamic softening characteristic. According to Figure 3,
Table 1: $\sigma_{\mathrm{p}}$ and its corresponding $\varepsilon_{\mathrm{p}}$ in the Ti-6Al-4V wire rod at the deformation temperatures of $400{ }^{\circ} \mathrm{C}, 500{ }^{\circ} \mathrm{C}, 600^{\circ} \mathrm{C}, 700{ }^{\circ} \mathrm{C}, 800{ }^{\circ} \mathrm{C}$, $900{ }^{\circ} \mathrm{C}$

\begin{tabular}{|c|c|c|c|}
\hline $\begin{array}{l}\text { Deformation } \\
\text { temperature } /{ }^{\circ} \mathrm{C}\end{array}$ & Strain rate $/ \mathrm{s}^{-1}$ & $\sigma_{\mathrm{p}} / \mathrm{MPa}$ & $\varepsilon_{\mathrm{p}}$ \\
\hline \multirow{3}{*}{400} & 0.1 & 928 & 0.64 \\
\hline & 1 & 843 & 0.38 \\
\hline & 10 & 857 & 0.39 \\
\hline \multirow{3}{*}{500} & 0.1 & 789 & 0.59 \\
\hline & 1 & 722 & 0.35 \\
\hline & 10 & 735 & 0.29 \\
\hline \multirow{3}{*}{600} & 0.1 & 600 & 0.29 \\
\hline & 1 & 590 & 0.23 \\
\hline & 10 & 617 & 0.27 \\
\hline \multirow{3}{*}{700} & 0.1 & 434 & 0.18 \\
\hline & 1 & 448 & 0.20 \\
\hline & 10 & 513 & 0.22 \\
\hline \multirow{3}{*}{800} & 0.1 & 275 & 0.30 \\
\hline & 1 & 347 & 0.14 \\
\hline & 10 & 419 & 0.15 \\
\hline \multirow{3}{*}{900} & 0.1 & 130 & 0.02 \\
\hline & 1 & 183 & 0.05 \\
\hline & 10 & 232 & 0.13 \\
\hline
\end{tabular}

the peak stress of each stress-strain curve and its corresponding strain are obtained, which are listed in Table $\mathbf{1 .}$ It can be seen from Table 1, when the deformation temperature increases from $400{ }^{\circ} \mathrm{C}$ to $900{ }^{\circ} \mathrm{C}$ at a deformation rate of $0.1 / \mathrm{s}$, the stress peak of the material is reduced from $928 \mathrm{MPa}$ to $130 \mathrm{MPa}$, and the strain corresponding to the stress peak is reduced from 0.64 to 0.02 . In this temperature range, the stress peak decreased by $14.9 \%, 23.9 \%, 27.7 \%, 36.6 \%$, and $52.7 \%$ for every temperature rise of $100{ }^{\circ} \mathrm{C}$. When the deformation temperature increases from $400{ }^{\circ} \mathrm{C}$ to $900{ }^{\circ} \mathrm{C}$ at the deformation rate of $1 / \mathrm{s}$, the stress peak of the material is reduced from $843 \mathrm{MPa}$ to $183 \mathrm{MPa}$, and the strain corresponding to the stress peak is reduced from 0.38 to 0.05 . In this temperature range, the stress peak decreased by $14.4 \%$, $18.3 \%, 24.1 \%, 22.5 \%$, and $43.7 \%$ for every temperature rise of $100{ }^{\circ} \mathrm{C}$. When the deformation temperature increases from $400{ }^{\circ} \mathrm{C}$ to $900{ }^{\circ} \mathrm{C}$ at a deformation rate of $10 / \mathrm{s}$, the stress peak of the material is reduced from 857 $\mathrm{MPa}$ to $232 \mathrm{MPa}$, and the strain corresponding to the

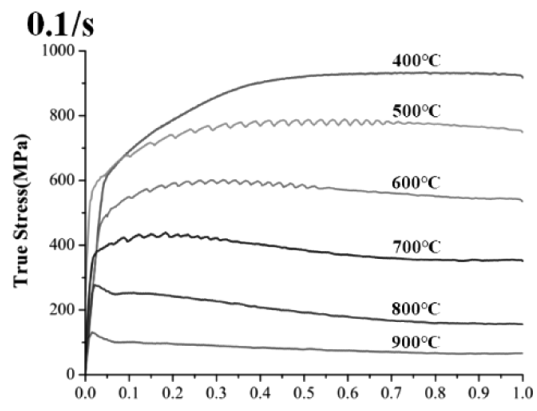

(a)

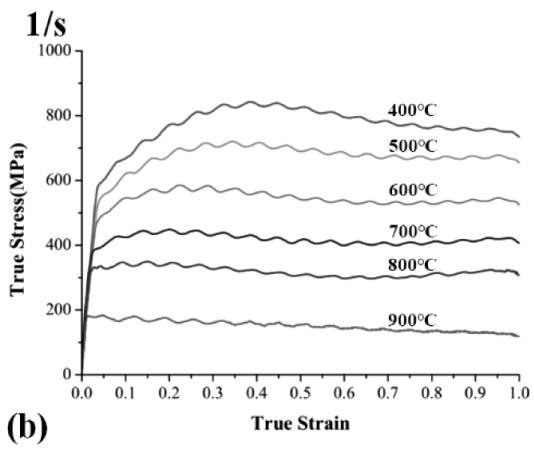

(b)

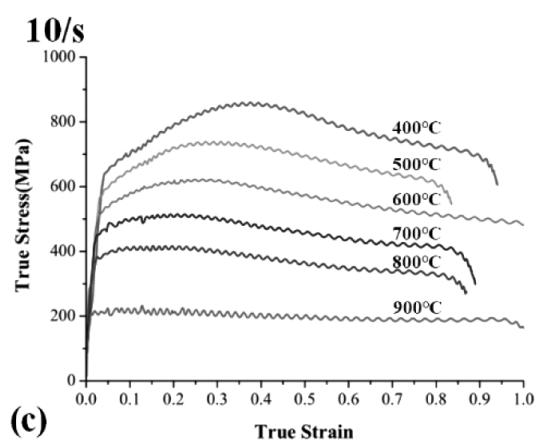

Figure 3: Stress-strain relationships of Ti-6Al-4V wire rod at deformation temperatures of $400{ }^{\circ} \mathrm{C}, 500{ }^{\circ} \mathrm{C}, 600{ }^{\circ} \mathrm{C}, 700{ }^{\circ} \mathrm{C}, 800{ }^{\circ} \mathrm{C}, 900{ }^{\circ} \mathrm{C}$ with strain rates of : a) $0.1 / \mathrm{s}$, b) $1 / \mathrm{s}$ and c) $10 / \mathrm{s}$ 

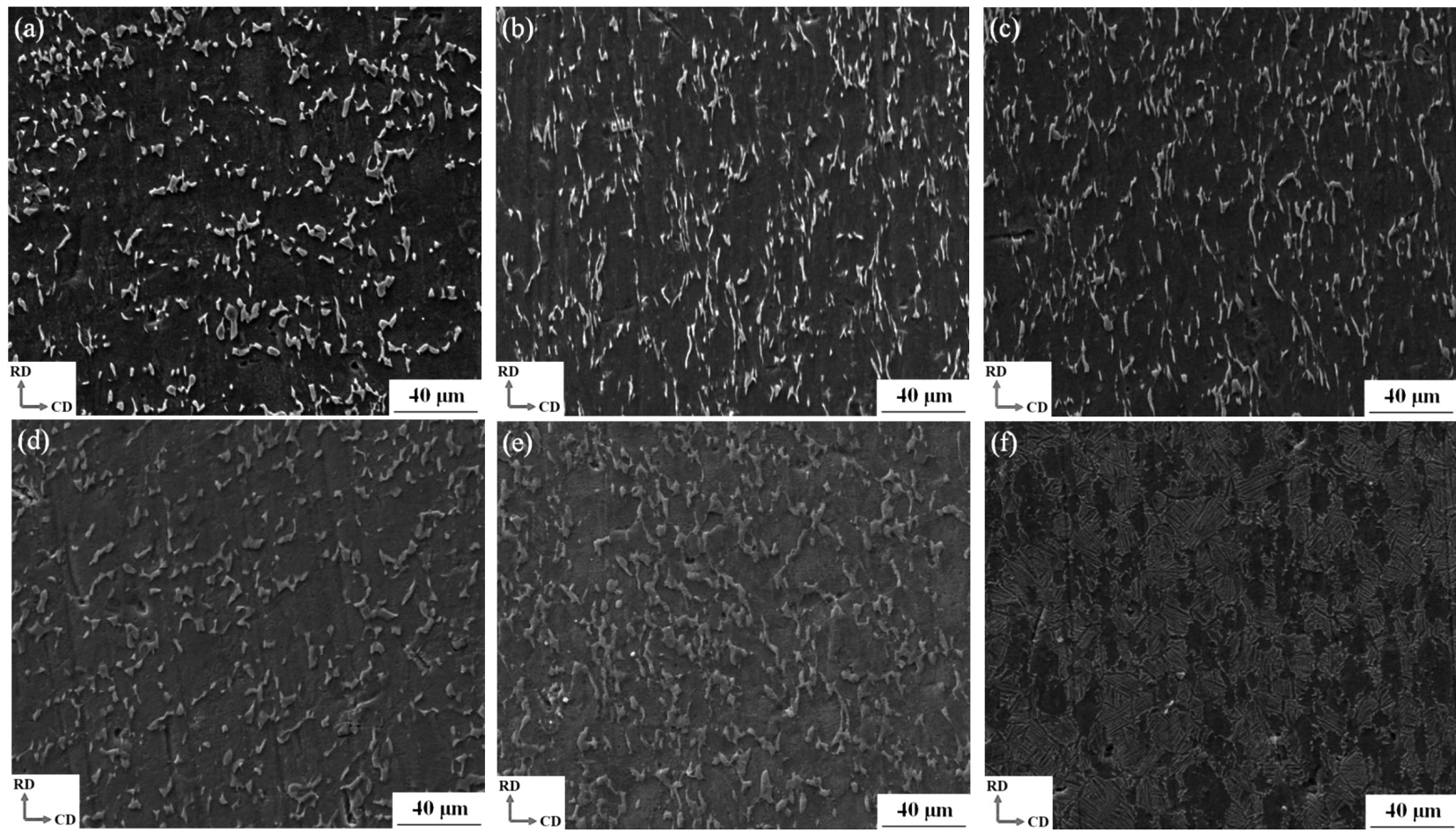

Figure 4: SEM microstructure of Ti- $6 \mathrm{Al}-4 \mathrm{~V}$ alloy wire rod at strain rate of $1 / \mathrm{s}$ with deformation temperatures of:a) $\left.\left.400{ }^{\circ} \mathrm{C}, \mathrm{b}\right) 500{ }^{\circ} \mathrm{C}, \mathrm{c}\right) 600{ }^{\circ} \mathrm{C}$, d) $700{ }^{\circ} \mathrm{C}$, e) $800{ }^{\circ} \mathrm{C}$, f) $900{ }^{\circ} \mathrm{C}$

stress peak is reduced from 0.39 to 0.13 . In this temperature range, the stress peak decreased by $14.2 \%, 16.1 \%$, $16.9 \%, 18.3 \%$, and $44.6 \%$ for every temperature rise of $100{ }^{\circ} \mathrm{C}$. This indicates that the deformation resistance decreases as the temperature increases. And, the stress-strain curve exhibits significant sawtooth at the higher strain rate, due to the repeated competition of the work hardening and recrystallization softening processes. In particular, the more pronounced the saw teeth takes place under the higher deformation temperature. Such curves are called non-continuous yield curves. ${ }^{16}$

Figure 4 shows the SEM microstructure of the Ti-6Al-4V alloy wire rod at strain rate of $1 / \mathrm{s}$ with temperatures of $400{ }^{\circ} \mathrm{C}, 500{ }^{\circ} \mathrm{C}, 600{ }^{\circ} \mathrm{C}, 700{ }^{\circ} \mathrm{C}, 800{ }^{\circ} \mathrm{C}$ (a) $400^{\circ} \mathrm{C}$

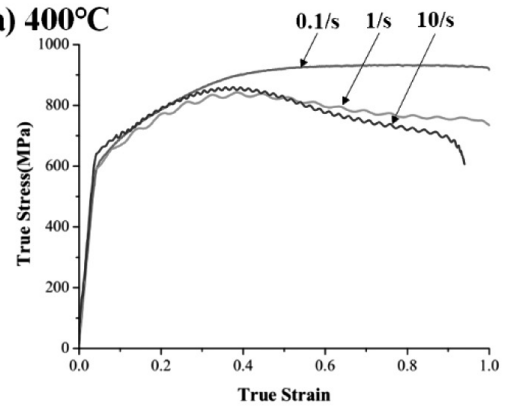

(d)

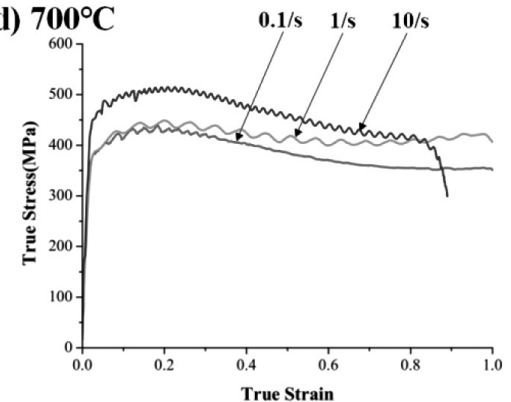

(b) $500^{\circ} \mathrm{C}$

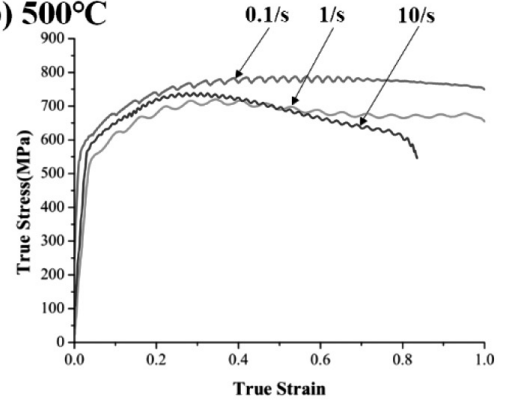

(e) $800^{\circ} \mathrm{C}$

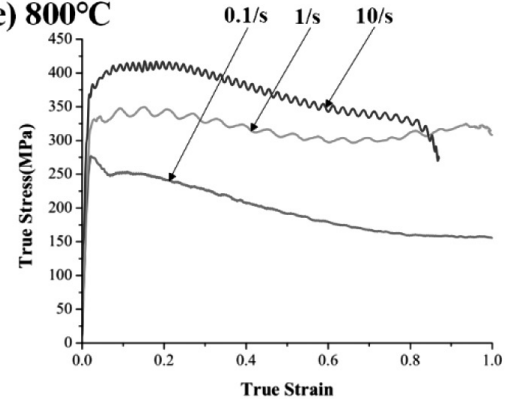

(c) $600^{\circ} \mathrm{C} \quad 0.1 / \mathrm{s} \quad 1 / \mathrm{s} \quad 10 / \mathrm{s}$

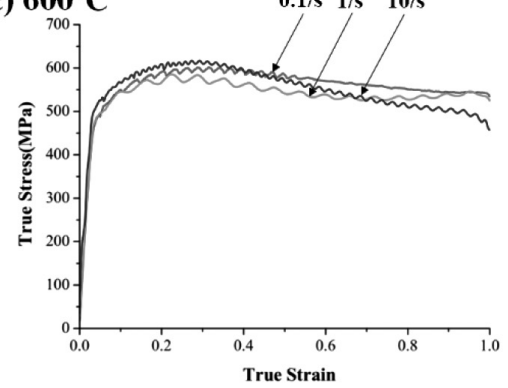

(f) $900^{\circ} \mathrm{C}$

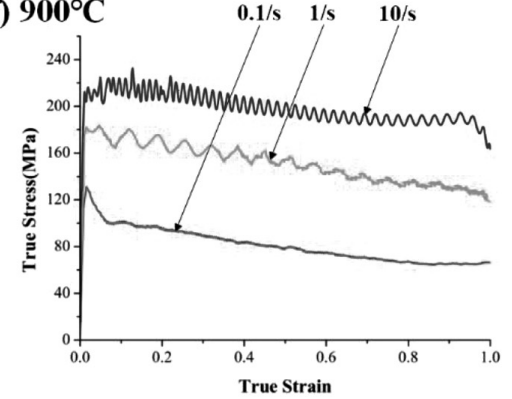

Figure 5: Stress-strain relationships of Ti-6Al-4V wire rod at strain rates of $0.1 / \mathrm{s}, 1 / \mathrm{s}, 10 / \mathrm{s}$ with temperatures of:a) $400{ }^{\circ} \mathrm{C}$, b) $500{ }^{\circ} \mathrm{C}$, c) $600{ }^{\circ} \mathrm{C}$, d) $700{ }^{\circ} \mathrm{C}$, e) $800{ }^{\circ} \mathrm{C}$, f) $900{ }^{\circ} \mathrm{C}$ 

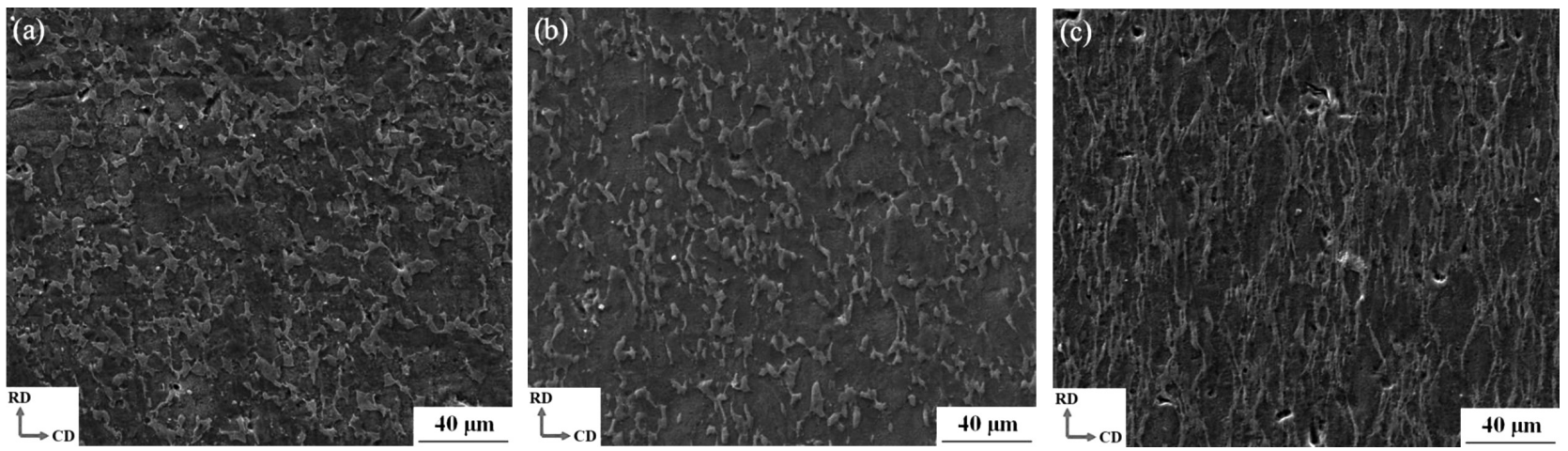

Figure 6: SEM microstructure of Ti- $6 \mathrm{Al}-4 \mathrm{~V}$ alloy wire rod at temperature of $800{ }^{\circ} \mathrm{C}$ and true strain of 1 with strain rates of:a) $\left.\left.0.1 / \mathrm{s}, \mathrm{b}\right) 1 / \mathrm{s}, \mathrm{c}\right) 10 / \mathrm{s}$

and $900{ }^{\circ} \mathrm{C}$. It can be seen from Figure 4 that the primary $\alpha$ phase is the black matrix, while the gray $\beta$ phase particles distributes in the matrix. At the deformation temperatures of $400-600{ }^{\circ} \mathrm{C}$, the $\beta$ phase particles change into long strips along the compression direction. The sizes of $\beta$ phase have little change. The shape change was caused by a local temperature rise. At the deformation temperatures of $700-900{ }^{\circ} \mathrm{C}$, the adjacent $\beta$ phase aggregates and grows with an increase of deformation temperature, and the content of $\beta$ phase increases significantly. At the temperature of $900{ }^{\circ} \mathrm{C}$, the needlelike microstructure appears obviously in the $\beta$ phase.

\subsection{Effect of deformation rates on the mechanical be- havior and microstructure evolution}

Figure 5 shows the stress-strain relationships of the Ti-6Al-4V wire rod at strain rates of $0.1 / \mathrm{s}, 1 / \mathrm{s}$ and $10 / \mathrm{s}$ with temperature of $400{ }^{\circ} \mathrm{C}, 500{ }^{\circ} \mathrm{C}, 600{ }^{\circ} \mathrm{C}, 700{ }^{\circ} \mathrm{C}$, $800{ }^{\circ} \mathrm{C}$ and $900{ }^{\circ} \mathrm{C}$. Dynamic softening is obvious in Figure 5. The flow stress decreases after it reaches the peak value and enters a stable stress state. It can be seen from Figure $\mathbf{5}$ that there are differences between 400-600 ${ }^{\circ} \mathrm{C}$ and $700-900{ }^{\circ} \mathrm{C}$ in metal flow softening. At $400-600{ }^{\circ} \mathrm{C}$, the stress value at the higher strain rate is lower than that at lower strain rate, which was caused by a local temperature rise. The temperature rise is directly related to the strain rate. With an increase of the strain rate, the temperature rise increases, which leads to material softening. ${ }^{17}$. When the deformation temperature is above $600{ }^{\circ} \mathrm{C}$, the stress value at the higher strain rate is higher than that at the lower strain rate, which conforms with the normal metal flow law. At $700-900{ }^{\circ} \mathrm{C}$, metal flow softening is predominated by the dynamic crystallization of the $\beta$ phase. ${ }^{2}$ Therefore, the softening mechanism is different for $400-600{ }^{\circ} \mathrm{C}$ and $700-900{ }^{\circ} \mathrm{C}$. The deformation temperature range from $400{ }^{\circ} \mathrm{C}$ to $600{ }^{\circ} \mathrm{C}$ can be regarded as the warm deformation region, and $700-900{ }^{\circ} \mathrm{C}$ can be regarded as the hot deformation region in this work.

Figure 6 shows an SEM microstructure of the Ti-6Al-4V alloy wire rod at a temperature of $800{ }^{\circ} \mathrm{C}$ and a true strain of 1 with strain rates of $0.1 / \mathrm{s}, 1 / \mathrm{s}$, and $10 / \mathrm{s}$.
As can be seen from Figure 6, when the strain rate is $0.1 / \mathrm{s}$, the $\beta$ phase of the Ti-6Al-4V alloy undergoes a certain degree of dynamic recrystallization due to the long deformation time. The $\beta$ phase is equiaxed, the grain size is larger, and nonuniformly distributes in the matrix. During the compression process, local temperature overheating is likely to occur, resulting in severe deformation. When the strain rate is $1 / \mathrm{s}$, the $\beta$ phase is elongated in a direction perpendicular to the compression. The grain size of the $\beta$ phase is significantly reduced, and the $\beta$ phase uniformly distributed in the matrix. When the strain rate is $10 / \mathrm{s}$, the $\beta$ phase structure is a severely deformed elongated strip structure because at a higher strain rate, the deformation time is shortened, and dynamic recovery and dynamic recrystallization cannot be sufficiently performed. Therefore, as the deformation rate increases, the $\beta$ phase changed mainly in terms of morphology, and at a higher strain rate, the microstructure exhibits significant directionality.

\subsection{Analysis of material flow softening during warm compression}

Figure 7 shows the true stress-strain curve and strain-hardening rate at $600{ }^{\circ} \mathrm{C}$ and a strain rate of $10 / \mathrm{s}$. As can be seen from Figure 8, the critical strain value is

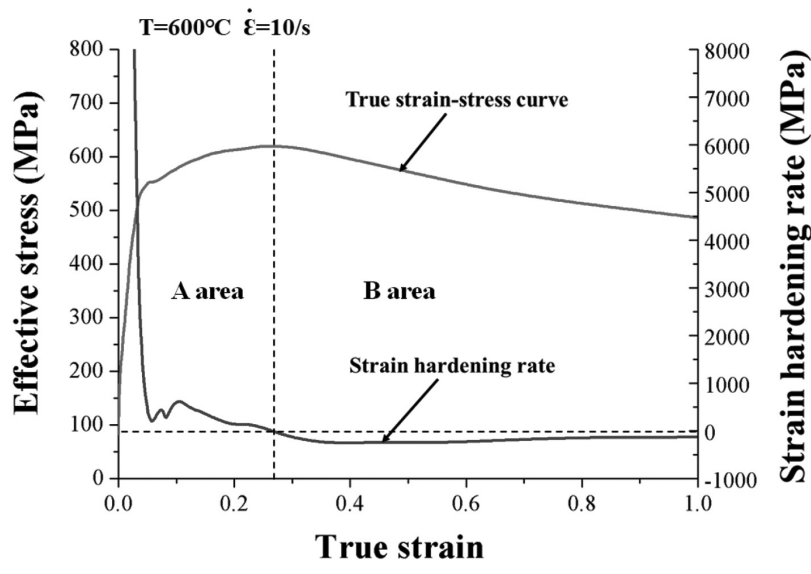

Figure 7: True stress-strain curve and strain-hardening rate at $600{ }^{\circ} \mathrm{C}$ and a strain rate of $10 / \mathrm{s}$ 


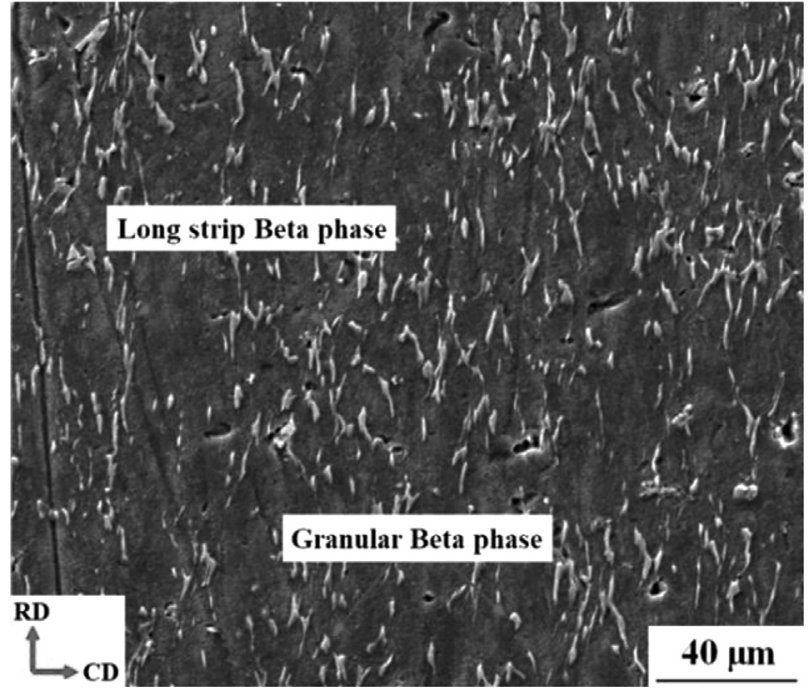

Figure 8: SEM microstructure of Ti-6Al-4V alloy wire rod at $600{ }^{\circ} \mathrm{C}$ and a strain rate of $10 / \mathrm{s}$

0.27. Figure 8 was divided into two regions: A and B. In the region $\mathrm{A}$, the effective stress increases as the strain increases, and the strain hardening rate was positive. In the region $\mathrm{B}$, the effective stress decreases as the strain increases, and the strain hardening rate was negative. The results show that the material flow softening of the Ti-6Al-4V wire rod occurs in region B.

Figure 8 shows the SEM microstructure of Ti-6Al-4V alloy wire rod at $600{ }^{\circ} \mathrm{C}$ and a strain rate of $10 /$ s. It can be seen from Figure 8 that after thermal compression deformation, there are two different forms of $\beta$ phase in the matrix, i.e., the granular $\beta$ phase and the long-strip $\beta$ phase. The thermal conductivity of the Ti-6Al-4V alloy is low at the deformation temperature of $600{ }^{\circ} \mathrm{C}$ and a strain rate of $10 / \mathrm{s}$, resulting in the heat generated by the compression deformation. The local temperature of the test piece cause adiabatic instability, which is the main reason for the flow softening during warm compression.

\section{CONCLUSIONS}

The Ti-6Al-4V compressed samples tend to be cracked along a $45^{\circ}$ angle below $300{ }^{\circ} \mathrm{C}$. The critical deformation temperature of the Ti-6Al-4V alloy is $300{ }^{\circ} \mathrm{C}$. The Ti-6Al-4V wire rod has poor formability when the deformation temperature is below $400{ }^{\circ} \mathrm{C}$, which should be avoided in the actual production process. Deformation temperature range from $400{ }^{\circ} \mathrm{C}$ to $600{ }^{\circ} \mathrm{C}$ can be regarded as the warm deformation region. The deformation temperature range from $700{ }^{\circ} \mathrm{C}$ to $900{ }^{\circ} \mathrm{C}$ can be regarded as the hot deformation region. And the softening mechanism was predominated by a temperature rise and dynamic recrystallization, respectively, for the warm deformation region and the hot deformation region of the Ti-6Al-4V alloy.
In the warm deformation region, the $\beta$ phase particles change into long strips along the compression direction. The sizes of the $\beta$ phase have little change. The shape change was caused by a local temperature rise. In the hot-deformation region, the adjacent $\beta$ phase aggregates and grows with an increase in the deformation temperature, and the content of $\beta$ phase increases significantly. In the hot deformation region, dynamic crystallization takes places at a lower strain rate for a given deformation temperature. However, insufficient crystallization appears at the higher strain rate, the $\beta$ phase becomes long strips in the matrix, and the microstructure exhibits significant directionality.

\section{Acknowledgments}

This project is funded by the National Natural Science Foundation of China (Grant No. 51805314), National Key Research and Development Program of China (Grant No. 2018YFB1307900), Shanghai Science and Technology Commission (Grant No. 16030501200).

\section{REFERENCES}

${ }^{1}$ Y. H, Qu, J. K. Sun, X. J. Meng, An investigation on mechanic behavior of tc4 alloy during hot compression deformation, Development and application of materials, 21 (2006) 2, 24-29, doi:10.3969/j.issn.1003-1545. 2006.02.006

${ }^{2}$ Y. S. Zhang, L. Y. Pan, J. T. Luo, X. F. Liu, Study on constitutive relationship for hot deformation of TC4 alloy, Hot Working Technology, 42 (2013) 2, 24-27, doi:10.14158/j.cnki.10013814. 2013.02.019

${ }^{3}$ L. J. Zhang, X. Y. Wang, Q. Y. Guo, T. Xie, X. Y. Xue, H. Chang, Application of Titanium Alloy in Chinese Aircraft Fastener, Aeronautical Manufacturing Technology, 120 (2013) 16, 129-133, doi:10.3969/j.issn.1671-833X.2013.16.030

${ }^{4}$ Y. Cai, High temperature tensile mechanical properties and tissue evolution of TC4 titanium alloy, Nanjing University of Aeronautics and Astronautics, 2009

${ }^{5}$ X. L. Yang, C. J. Ge, Z. Yang, Effect of deformation temperature on warm deformation behavior of TC4 alloy, Hot Working Technology, 41 (2012) 16, 71-73, doi: 10.14158/j.cnki. 10013814.2012.16.054

${ }^{6}$ B. Li, P. Zhang, Study on the correlation of flow behavior and microstructure evolution during the high temperature tensile deformation of TC4 alloy, Forging \& Stamping Technology, 40 (2015) 6, 108-115, doi:10.13330/j.issn.1000-3940.2015.06. 023

${ }^{7}$ Z. M. Cai, H. C. Ji, W. C. Pei, X. F. Tang, X. M. Huang, J. P. Liu, Hot workability, constitutive model and processing map of $3 \mathrm{Cr} 23 \mathrm{Ni} 8 \mathrm{Mn} 3 \mathrm{~N}$ heat resistant steel, Vacumn, 165 (2019) 4, 324-336, doi:10.1016/j.vacuum.2019.04.041

${ }^{8}$ H. J. Mao, J. M. Cao, H. B. Yang, Annealing microstructure and properties of fine-grained TC4 wire, The Nonferrous Metals Society of China, Proceedings of the 15th National Titanium and Titanium Alloy Academic Exchange Conference, Harbin, 2013, 105-110

${ }^{9}$ Z. Q. Wu, Z. Q. Zhang, L. M. Dong, Microstructure and mechanical properties of Ti6A14V alloy for fasteners, Journal of Materials Heat Treatment, 34 (2013) 9, 122-126, doi:10.13289/j.issn.1009-6264. 2013.09.026

${ }^{10}$ L. F. Mao, M. R. Shuai, J. P. Qin, C. J. Zhao, Study on Thermodynamic Behavior and Rolling Technique of Rod for TC4 Titanium Alloy, Hot Working Technology, 43 (2014) 1, 48-51, doi:10.14158/ j.cnki.1001-3814.2014.01.045 
${ }^{11}$ B. L. Luo, H. J. Mao, X. K. Yang, G. D. Wang, R. Hou, L. N. Ren, Analysis of Microstructure Uniformity of TC4 Titanium Alloy in Continuous Rolling Process, Hot Working Technology, 46 (2017) 11, 67-70, doi:10.14158/j.cnki.1001-3814.2017. 11.018

${ }^{12}$ Z. M. Cai, H. C. Ji, W. C. Pei, B. Y. Wang, X. M. Huang, Y. M. Li, Constitutive equation and model validation for $33 \mathrm{Cr} 23 \mathrm{Ni} 8 \mathrm{Mn} 3 \mathrm{~N}$ heat-resistant steel during hot compression, Results in Physics, 15 (2019), 102633, doi: 10.1016/j.rinp.2019.102633

${ }^{13}$ Y. M. Li, H. C. Ji, Z. M. Cai, X. F. Tang, Y. G. Li, J. P. Liu, Comparative study on constitutive models for 21-4N heat resistant steel during high temperature deformation, Materials, 12 (2019) 12, 1893, doi:10.20944/preprints2019.05.0249

${ }^{14}$ B. F. Wang, Y. Yang, Microstructure evolution in adiabatic shear band in fine-grain-sized Ti-3Al-5Mo-4.5V alloy, Materials Science
\& Engineering, A. Structural Materials: Properties, Microstructure and Processing, 473 (2008) 1-2, 306-311, doi:10.1016/j.msea.2007. 03.073

${ }^{15}$ C. J. Ge, X. L. Yang, Z. Mou, Study on Temperature Deformation Adiabatic Shear Band of TC4 Alloy, Hot Working Technology, 42 (2013) 19, 91-94, doi:10.14158/j.cnki.1001-3814.2013.19.050

${ }^{16}$ X. T. Wang, Constitutive Modeling and Computation of High Temperature Viscoplastic Deformation of $\beta$ Titanium Alloy, Harbin Institute of Technology, 2009

${ }^{17}$ Y. Xu, X. J. Yang, Y. He, D. N. Du, Flow Softening Behavior and Constitutive Equation of TC4 Titanium Alloy during Hot Deformation, Rare Metal Materials and Engineering, 46 (2017) 5, 1321-1326, doi:cnki:sun:cose.0.2017-05-029 